\title{
Simpósio Nacional de Diagnóstico de Enfermagem: building a knowledge field for Nursing
}

\author{
Simpósio Nacional de Diagnóstico de Enfermagem: construindo um campo de conhecimento para a Enfermagem
}

Simpósio Nacional de Diagnóstico de Enfermagem: construyendo un campo de conocimiento para la Enfermería

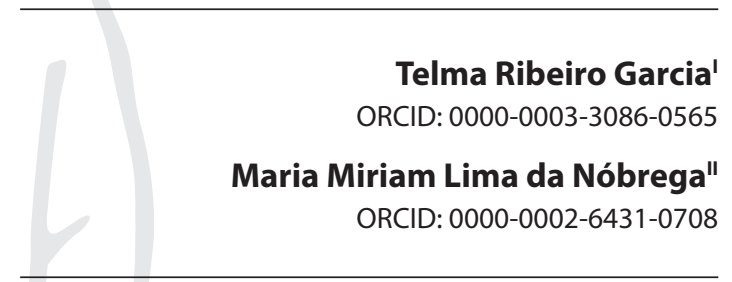

'Associação Brasileira de Enfermagem Nacional, Comissão de Sistematização da Prática de Enfermagem, Gestão 2016-2019. João Pessoa, Paraíba, Brasil. "Universidade Federal da Paraíba, Centro de Ciências da Saúde. João Pessoa, Paraíba, Brasil.

How to cite this article: Garcia TR, Nóbrega MML. Simpósio Nacional de Diagnóstico de Enfermagem: building a knowledge field for Nursing. Rev Bras Enferm [Internet]. 2019;72(3):801-8. doi: http://dx.doi.org/10.1590/0034-7167-2018-0916

Corresponding Author: Telma Ribeiro Garcia E-mail: telmagarciapb@gmail.com

Submission: 11-24-2018 Approval: 12-04-2018

\section{ABSTRACT}

Objective: to recount the story of the Simpósio Nacional de Diagnóstico de Enfermagem (National Nursing Diagnosis Symposium), from 1991 to 2018, describing the official themes and main recommendations; and reflect on the construction, in this process, of a specific field of knowledge for Nursing. Results: the manuscript became a historical study, using official documents resulting from the thirteen Symposiums conducted in the period from 1991 to 2018 as the primary source of empirical data. The outcomes were divided into two stages, from 1991 to 1992, when the event was linked to Interest Groups in Nursing Diagnosis; and from 1996 to 2018, when ABEn Nacional took over the organization and execution of the event. Final considerations: the socialization and exchange of knowledge about systematization of care, Nursing Process and nursing terminologies, themes focused on SINADEn, contributed decisively to the construction of a fruitful field of knowledge for Nursing.

Descriptors: Nursing; Nursing Process; Nursing Diagnosis; Terminology; Standardized Nursing Terminology.

\section{RESUMO}

Objetivo: resgatar a história do Simpósio Nacional de Diagnóstico de Enfermagem, de 1991 a 2018, descrevendo as temáticas oficiais e principais recomendações; e refletir sobre a construção, nesse processo, de um campo específico de conhecimento para a Enfermagem. Resultados: o manuscrito assumiu o caráter de um estudo histórico, utilizando-se documentos oficiais resultantes dos treze Simpósios realizados no período de 1991 a 2018 como fonte primária de dados empíricos. Os resultados foram divididos em duas etapas, de 1991 a 1992, quando o evento esteve vinculado a Grupos de Interesse em Diagnóstico de Enfermagem; e de 1996 a 2018, quando a ABEn Nacional assumiu a organização e execução do evento. Considerações finais: a socialização e intercâmbio do conhecimento sobre sistematização da assistência, Processo de Enfermagem e terminologias de enfermagem, temas focalizados nos SINADEn, têm contribuído decisivamente para a construção de um fecundo campo de conhecimento para a Enfermagem.

Descritores: Enfermagem; Processo de Enfermagem; Diagnóstico de Enfermagem; Terminologia; Terminologia Padronizada em Enfermagem.

\section{RESUMEN}

Objetivo: rescatar la historia del Simpósio Nacional de Diagnóstico de Enfermagem (Simposio Nacional de Diagnóstico de Enfermería), de 1991 a 2018, describiendo las temáticas oficiales y principales recomendaciones; y reflexionar sobre la construcción, en ese proceso, de un campo específico de conocimiento para la Enfermería. Resultados: el manuscrito asumió el carácter de un estudio histórico, utilizando documentos oficiales resultantes de los trece Simposios realizados en el período de 1991 a 2018 como fuente primaria de datos empíricos. Los resultados fueron divididos en dos etapas, de 1991 a 1992, cuando el evento estuvo vinculado a Grupos de Interés en Diagnóstico de Enfermería; y de 1996 a 2018, cuando la ABEn Nacional asumió la organización y ejecución del evento. Consideraciones finales: la socialización e intercambio del conocimiento sobre sistematización de la asistencia, Proceso de Enfermería y terminologías de enfermería, temas focalizados en los SINADEn, han contribuido decisivamente a la construcción de un fecundo campo de conocimiento para la Enfermería.

Descriptores: Enfermería; Processo de Enfermería; Diagnóstico de Enfermería; Terminología; Terminología Normalizada de Enfermería. 


\section{INTRODUCTION}

As a result of the activity of naming and assigning meaning to the phenomena and activities pertinent to the profession, nursing has systematically and continuously developed a body of specific knowledge, which includes concepts that are within its field of activity and which are applicable in any field of professional practice - teaching, care, research and management/ administration of nursing care and human resources ${ }^{(1)}$.

The International Council of Nurses (ICN) considers three elements to be essential and, therefore, inseparable from the professional practice and its documentation: judgments or assessments of human needs (nursing diagnoses); actions taken to positively influence diagnoses in human and social needs (nursing actions or interventions); and outcomes sensitive to nursing actions or interventions (nursing outcomes) ${ }^{(2)}$.

In turn, the Associação Brasileira de Enfermagem (Brazilian Nursing Association, ABEn Nacional), throughout its history, emphasizes the ethical and legal responsibility of professionals to operationalize and, above all, to document the Nursing Process, a theoretical and methodological tool inherent in the caring process and the right of citizens as users of health services and actions to a safe, dignified, sensitive, competent and resolutive nursing care ${ }^{(3)}$.

Thus, ABEn Nacional regularly promotes the Simpósio Nacional de Diagnóstico de Enfermagem (National Nursing Diagnosis Symposium), whose main purpose is the exchange and socialization of knowledge about the Systematization of Nursing Care and the Nursing Process, and about standardized language systems of nursing, which organize, in terminologies, the concepts agreed upon by professionals to describe diagnoses, interventions and outcomes pertinent to nursing care ${ }^{(4)}$, concepts that should be applied to all fields of the professional practice.

In view of the mentioned aspects, the elaboration of this manuscript aimed to rescue the Simpósio Nacional de Diagnóstico de Enfermagem, describing the historical development of the official themes and the main recommendations resulting from the thirteen editions of the event, which occurred between 1991 and 2018; and reflect on the construction, in this process, of a fruitful field of knowledge for Nursing.

The manuscript became a historical study in which, to describe the intentional aspects, the official documents resulting from the thirteen Symposiums from 1991 to 2018 were used as primary sources of empirical data - Programs, Annals, Reports, Charters, and books of the Didactic Series: Enfermagem no SUS, published by ABEn. Some of these documents were accessed through the library of the Centro de Memória da Enfermagem Brasileira (Memory of Brazilian Nursing Center), or the Events Portal of ABEn Nacional (http://www.abeneventos.com.br/aben_eventos.html); others are part of the private collection of the authors. As described in Chart 1 , official documents of the thirteen Symposiums were obtained and, for some of them, more than one document. The description of outcomes was divided into two stages: from 1991 to 1992, when the event was linked to Interest Groups in Nursing Diagnosis (GIND); and from 1996 to 2018, when ABEn Nacional took over the organization and execution of the event (Chart 1).

Chart 1 - Editions of the Simpósio Nacional de Diagnóstico de Enfermagem, according to the number of orders, year of accomplishment, location, central theme and document(s) accessed - 1991 to 2018

\begin{tabular}{|c|c|c|c|c|}
\hline $\mathrm{N}^{\circ}$ of order & Year & Place & Central Theme & Document(s) accessed \\
\hline \multicolumn{5}{|c|}{ First stage - 1991 to 1992} \\
\hline $1^{\text {st }} \mathrm{SNDE}$ & 1991 & São Paulo & $\begin{array}{l}\text { Nursing diagnosis, its taxonomy and its impact on } \\
\text { teaching and practice }\end{array}$ & Annals \\
\hline $2^{\text {nd }}$ SNDE & 1992 & João Pessoa & Uniformization of nursing diagnoses in Brazil & $\begin{array}{l}\text { Annals } \\
\text { Book: Uniformização da linguagem dos diagnósticos } \\
\text { de enfermagem da NANDA: sistematização das } \\
\text { propostas do /l SNDE }\end{array}$ \\
\hline \multicolumn{5}{|c|}{ Second stage - 1996 to 2018} \\
\hline $3^{\text {rd }}$ SINADEn & 1996 & Fortaleza & $\begin{array}{l}\text { Nursing diagnosis: the way to the classification of } \\
\text { nursing practice }\end{array}$ & $\begin{array}{l}\text { Program } \\
\text { Book of the Didactic Series: Enfermagem no SUS (1): } \\
\text { O uso do diagnóstico na prática de enfermagem }\end{array}$ \\
\hline $4^{\text {th }}$ SINADEn & 1998 & Curitiba & Nursing diagnosis as a nursing work tool & Annals \\
\hline $5^{\text {th }}$ SINADEn & 2000 & João Pessoa & $\begin{array}{l}\text { Sistemas de classificação da prática de enfermagem: } \\
\text { um trabalho coletivo }\end{array}$ & $\begin{array}{l}\text { Program and Abstracts } \\
\text { Book of the Didactic Series: Enfermagem no SUS (2): } \\
\text { Sistemas de classificação da prática de enfermagem: } \\
\text { um trabalho coletivo }\end{array}$ \\
\hline $6^{\text {th }}$ SINADEn & 2002 & São Paulo & Making the quality of nursing care visible & $\begin{array}{l}\text { Book Program } \\
\text { Scientific Report }\end{array}$ \\
\hline $7^{\text {th }}$ SINADEn & 2004 & Belo Horizonte & $\begin{array}{l}\text { Systematization of Nursing Care and the Brazilian } \\
\text { Unified Health System (Sistema Único de Saúde) }\end{array}$ & Annals \\
\hline $8^{\text {th }}$ SINADEn & 2006 & João Pessoa & $\begin{array}{l}\text { Tracing paths in the construction of a Brazilian } \\
\text { nursing terminology }\end{array}$ & $\begin{array}{l}\text { Annals } \\
\text { Carta de João Pessoa (João Pessoa Charter) }\end{array}$ \\
\hline $9^{\text {th }}$ SINADEn & 2008 & Porto Alegre & $\begin{array}{l}\text { Brazilian contribution to the development of nursing } \\
\text { classifications }\end{array}$ & Scientific Report \\
\hline $10^{\text {th }}$ SINADEn & 2010 & Brasília & $\begin{array}{l}\text { Systematization of Nursing Care in Brazil: } 30 \text { years in } \\
\text { the construction of quality care }\end{array}$ & Annals \\
\hline
\end{tabular}


Chart 1 (concluded)

\begin{tabular}{|c|c|c|l|l|}
\hline $\mathbf{N}^{\circ}$ of order & Year & Place & \multicolumn{1}{|c|}{ Central Theme } & \multicolumn{1}{c|}{ Document(s) accessed } \\
\hline $11^{\text {th }}$ SINADEn & 2013 & Curitiba & $\begin{array}{l}\text { Systematization of Nursing Care and social } \\
\text { responsibility in the fields of professional practice }\end{array}$ & $\begin{array}{l}\text { Annals } \\
\text { Carta de Curitiba (Curitiba Charter) }\end{array}$ \\
\hline $12^{\text {th }}$ SINADEn & 2016 & Recife & $\begin{array}{l}\text { Systematization of Nursing Care: advances and } \\
\text { challenges in the quality of care, management, } \\
\text { teaching and research }\end{array}$ & $\begin{array}{l}\text { Annals } \\
\text { Carta de Recife (Recife Charter) }\end{array}$ \\
\hline $13^{\text {th }}$ SINADEn* & 2018 & Florianópolis & $\begin{array}{l}\text { National Curriculum Standards, Professional Training } \\
\text { and Systematization of Nursing Care }\end{array}$ & $\begin{array}{l}\text { Annals } \\
\text { Carta de Florianópolis (Florianópolis Charter) }\end{array}$ \\
\hline
\end{tabular}

Note: * In 2018, the $13^{\text {th }}$ SINADEn took place along with the $16^{\circ}$ Seminário Nacional de Diretrizes para a Educação em Enfermagem (16 th National Seminar of Nursing Education Standards).

\section{Simpósio Nacional de Diagnóstico de Enfermagem, 1991 to 2018}

\section{First stage - 1991 to 1992}

Simpósio Nacional de Diagnóstico de Enfermagem, whose initial acronym was SNDE, had its beginning linked to Interest Groups in Nursing Diagnosis (GIDE), formed by nurses who met periodically to deepen knowledge about nursing diagnoses, their taxonomy and clinical application. The GIDE were responsible for the organization of two SNDEs, respectively, in 1991 - GIDE São Paulo and, in 1992 - GIDE Paraíba.

The $1^{\text {st }}$ SNDE took place in November 1991, in São Paulo City São Paulo State. It was organized by GIDE São Paulo and promoted by the Instituto Dante Pazzanese de Cardiologia and by the Nursing Department of the Escola Paulista de Medicina. The event had as its central theme Nursing diagnosis, its taxonomy and its impact on teaching and practice ${ }^{(5)}$. The opening conference, entitled The context of nursing diagnosis, was delivered by Professor Doctor Tamara Iwanow Cianciarullo, who refers to the "discovery of the nursing diagnosis within the Nursing Process" as a promising fact by bringing the possibility of a common language and a taxonomy to be studied and validated; by demystifying the Nursing Process and transforming its phases/stages into professional commitment with the outcomes of nursing actions/interventions; by enabling the characterization of care subjects as strictly linked to the clients' responses, instead of focusing on the "worker behaviors" of nurses; and by making possible an expression of nurses skills and the definition of their professional responsibilities regarding clients' responses to nursing interventions ${ }^{(6)}$.

During the $1^{\text {st }} \mathrm{SNDE}$, the teaching and practice of the nursing diagnosis were addressed; as well as the meaning and historical evolution of the concept of nursing diagnosis; the organization of knowledge and the development of conceptual models and theories regarding nursing diagnoses; the perspective of universalizing the terms of the taxonomy of nursing diagnoses, highlighting the need to incorporate differences in language and culture when considering the international use of these diagnoses; considerations on clinical judgment in Nursing; the facilities and difficulties of their use in professional practice and the possibilities of quantitative and qualitative research applicable to studies with nursing diagnoses. The need for nurses to continue producing studies in this field and to promote new meetings for the socialization of their outcomes was highlighted among the recommendations ${ }^{(5)}$.

In 1992, there was the $2^{\text {nd }}$ SNDE, in João Pessoa City - Paraíba State, concomitant with the III Seminário Paraibano de Diagnóstico de Enfermagem ( $3^{\text {rd }}$ SPDE - $3^{\text {rd }}$ Paraibano Seminar of Nursing Diagnosis). The central theme was the Uniformization of nursing diagnostics in Brazil, motivated by the identification of a lack of uniformity in the translation of the terms of NANDA Taxonomy I into Portuguese, among other aspects: a) differences related to the denomination of the Human Responses Patterns, now translated as nouns, or as verbs in the infinitive or in the gerund; b) differences between authors in the translation of some diagnostic titles, in their defining characteristics or in related factors. Thus, the $2^{\text {nd }}$ SNDE, despite focusing on other aspects pertinent to the theme, it was characterized by gathering efforts of the nursing community present at this event, in the sense of improving the translation of Taxonomy I of NANDA into Portuguese, which was made from each of the Human Responses Patterns - Change, Communicate, Relate, Appreciate, Choose, Move, Realize, Know and Feel ${ }^{(7)}$.

At the end of the $2^{\text {nd }}$ SNDE, it was decided in a plenary session that a synthesis of the proposals formulated during this event for the analysis and approval of participants, especially those involved in the study and application of the nursing diagnoses. As a result of this process, the book entitle Uniformização da linguagem dos diagnósticos de enfermagem da NANDA: sistematização das propostas do II SNDE was published in 1994, which included changes in the way taxonomy components (title, definition, defining characteristics and related factors) were translated into Portuguese, in addition to suggesting changes in these components (additions, withdrawals, translocations), which sometimes signified marked changes in diagnoses as approved by NANDA for clinical testing and use. Considering that, a work of refinement and validation of these proposals was recommended, which should be the subject of the next symposium ${ }^{(8)}$.

At this point of the description, it is necessary to open a parenthesis to highlight two facts that certainly had a decisive influence on the directions of the construction of knowledge about standardized nursing language systems in Brazil. The first of these events was the participation of a delegation of representatives of ABEn Nacional in the Reunião Consultiva sobre o Desenvolvimento de uma Ferramenta para Apoiar os Sistemas de Informação de Enfermagem na Comunidade e na Atenção Primária à Saúde (Consultative Meeting on the Development of a Tool to Support Nursing Information Systems in the Community and in Primary Health Care), promoted by INC, from January 31 to February 5, 1994, in Tlaxcala, Mexico. The Brazilian delegation participated actively in the discussions that took place at this meeting and made, on behalf of $A B E n$, the commitment to elaborate a project focused on the intention of INC, namely, to identify concepts (diagnoses, interventions and nursing outcomes) Primary Health Care, in order to contribute to the expansion of the International Classification for Nursing Practice - ICNP', a standardized language system whose elaboration was under the responsibility of INC. In 
Brazil, this project, funded by WK Kellogg Foundation, was called the International Classification of Nursing Practices in Collective Health (ICNPCH ${ }^{\circ}$ ) and was carried out from 1996 to 2000, involving hundreds of ABEn members and having an important impact on teaching, care and research in Brazilian Nursing ${ }^{(9)}$.

The second event was the $1^{\text {st }}$ International Conference on Nursing Diagnosis, from October 20 to 22, 1995, at USP's Escola de Enfermagem, in São Paulo City - São Paulo State, Brazil. Professor June Clark, of the University of Middlesex, in London, participated in this event as one of the international guests, who spoke at the conference named An International Classification for Nursing Practice: limits and perspectives. Professor June Clark, as one of the consultants of the ICNP ${ }^{\circ}$ Project, described the progress made since 1989 when a resolution of the Council of Representatives of National Associations affiliated to the INC approved the preparation of the ICNP'. In her lecture, the participation of National Associations affiliated to the INC was highlighted, among them ABEn Nacional, in the meeting held in 1994 in Tlaxcala, Mexico, where these Associations made a commitment to elaborate a project that would meet the need for identifying concepts of nursing practice focused on Primary Health Care $^{(10)}$.

These two facts were considered decisive to make even more clear the involvement of ABEn Nacional with the thematic of the elements of practice of nursing and the systems of management of information of nursing classification systems, tools that must be available to nurses to identify their practice and specify their field of action, and to describe nursing and its contribution to the clientele's health.

\section{Second stage - 1996 to 2018}

From 1996, Simpósio Nacional de Diagnóstico de Enfermagem was incorporated into the official calendar of events of ABEn Nacional, being its organization under the responsibility of the Board of Professional Affairs. Today, according to the Bylaws in force, it is incumbent upon the Board of Development of Professional Practice and Nursing Work, in coordination with Comissão Permanente de Sistematização da Prática de Enfermagem (Standing Committee on Systematization of Nursing Practice), to coordinate its organization and execution. Since then, a new acronym has been adopted for the event - SINADEn, giving continuity to its sequenced numbering.

The new phase began with the $3^{\text {rd }}$ SINADEn, held in 1996, in Fortaleza City - Ceará State, with the central theme Nursing diagnosis: the way to the classification of nursing practice. In this event, although the state of art regarding teaching, research and application in the nursing practice of nursing diagnoses has not been neglected, the importance attributed to Brazil's participation in the $\mathrm{CIE}^{\circ}$ project is already clearly seen in the construction of ICNP', subject that was present in the speech of several lecturers ${ }^{(11)}$. As a result of the event, a Didactic Series was inaugurated by ABEn Nacional, called Enfermagem no SUS. The first copy of this series, 'The use of diagnosis in nursing practice', contains the papers presented by the lecturers of the $3^{\text {rd }}$ SINADEn, which sought to contribute to the debate on the use of nursing diagnosis, understood as a technological tool in the development of processes and the qualification of nursing care performed in Brazil ${ }^{(12)}$.
In 1998, the $4^{\text {th }}$ SINADEn was held, in Curitiba City - Paraná State. The central theme - Diagnosis as a Nursing work tool, reflected the theoretical and methodological framework that underpinned the initial design of the CIPESC CIE-ABEn Project (ICNPCH INC-ABEn). As an international guest, Professor Amy Coenen and ICNP Project Coordinator, from Marquette University College of Nursing, Milwaukee-WI, represented the INC at SINADEn, lecturing the International Classification for Nursing Practice (ICNP ${ }^{\circ}$ ): a unifying framework. In this event, the experience of the ICNP Project that was being developed in Chile was reported; however, the aspects still required by nursing professionals about the theme prevailed in the schedule, namely: strategies for teaching nursing diagnosis in undergraduate, postgraduate and continuing education; cognitive processes for the development of skills to establish nursing diagnoses; and research processes to validate nursing diagnoses ${ }^{(13)}$.

At the end of the $4^{\text {th }}$ SINADEn, ABEn - Paraíba Section proposed to host the next edition of the event. Given the stage reached in the ICNPCH INC-ABEn Project and the need for an opportunity to disseminate the outcomes obtained in Brazil and in other Latin American countries involved with similar projects, the coordination of the ICNPCH's Central Nucleus suggested the summation of efforts to carry out, in 2000, two simultaneous events - the $5^{\text {th }}$ SINADEn and the / Simpósio Internacional de Classificação da Prática de Enfermagem em Saúde Coletiva ( $1^{\text {st }}$ International Conference on Classification of Nursing Practice in Collective Health). The central theme proposed, Sistemas de classificação da prática de enfermagem: um trabalho coletivo, and the insertion of the "nurse bee" in its logo, represented the understanding of the Executive Committee of the two events that "the construction of knowledge in Nursing must be done by the embracing of hands, union of ideas and wish/desire to defend hope". During the period of its execution, the ICNPCH INC-ABEn Project (developed in Brazil) outcomes were published, as well as those of ICNP ${ }^{\circ}$ Projects, developed in Colombia and Chile. In addition, the event provided an exchange of knowledge between the national and international nursing community on the use of nursing practice classification systems; the work process and the specific knowledge of this profession, its terminology and the use of this terminology in practice (teaching, care, research and management/administration), among other aspects pertinent to both events ${ }^{(14-15)}$.

In 2002, ABEn - São Paulo Section oversaw the delivery of the $6^{\text {th }}$ SINADEn and the ISimpósio Internacional sobre Classificações de Enfermagem. These two events were organized with the purpose of broadening the discussion and deepening the knowledge about the link between NANDA classification of diagnoses, the nursing interventions classifications (NIC) and nursing outcomes (NOC). In view of this, the event was attended by two of the principal researchers of the Center of Nursing Classification, University of lowa, Professor Joanne McCloskey Dochterman and Professor Gloria Bulechek. With the exception of a panel discussing Nursing classifications in collective health: the ICNPCH Project, the whole program of $6^{\text {th }}$ SINADEn revolved around the NANDA, NIC and NOC classifications, aiming to familiarize nurses with the nursing classifications of interventions and outcomes; and enable them to understand the connection between NANDA, NIC and NOC regarding care, teaching and research ${ }^{(16)}$. 
The presence of the Board of Directors of ABEn Nacional and the representatives of the main groups of Brazilian researchers in the area of classifications for the nursing practice not only allowed the enrichment of discussions during the activities of the $6^{\text {th }}$ SINADEn program, but also the accomplishment of a meeting between these leaders, with the objective to discuss the course of work with classifications in the country. Among the issues addressed, the following stand out: 1) the proposal to change the name of SINADEn, which would have a wider denomination - Simpósio Nacional sobre Classificações de Enfermagem, in order to include other standardized language systems in use in the country, such as NIC, NOC and ICNP; ; and 2) ABEn's decision to create, in its structure, a Departamento Cientifico de Classificação, Intervenções, Diagnósticos e Resultados da Prática de Enfermagem (DECIDIRE - Scientific Department of Classification, Interventions, Diagnoses and Outcomes of Nursing Practice), linked to the Scientific-Cultural Board and with the collaboration of the Board of Professional Affairs and the Center for Studies and Research in Nursing ${ }^{(17)}$.

The proposal to change the denomination of the event was not approved in the decision-making bodies of ABEn Nacional. As for the second point, although the existence of a decision to create the DECIDIRE at the time of $6^{\text {th }}$ SINADEn, , its fulfillment only occurred in the second term of Francisca Valda da Silva as President of ABEn Nacional, 2004-2007 term in office. In the course of history, under the recommendation by the National Board and unanimous approval of the Conselho Nacional da ABEn (National Council of ABEn - CONABEn), DECIDIRE was replaced in 2008 by the Subcommittee on Systematization of Nursing Practice, linked to the Board of Professional Affairs. In 2013, with the approval of a new Bylaw for the entity, this Subcommittee became known as the Standing Committee on Systematization of Nursing Practice, as one of the statutory advisories and consulting bodies of ABEn Nacional.

Returning to the historical rescue of Simpósio Nacional de Diagnóstico de Enfermagem in 2004, the ABEn - Minas Gerais Section was responsible for carrying out the $7^{\text {th }}$ SINADEn, with the central theme of Systematization of Nursing Care and the Brazilian Unified Health System (Sistema Único de Saúde). According to members of the Scientific Subcommittee, ABEn - Minas Gerais Section received that year, with affection and certainty of a better future,

the nursing community interested in collective construction of nursing classifications; in the definition, recognition and validation of nursing diagnoses, interventions and outcomes, aiming to contribute to the collective construction of a nursing know-how packaged by science committed to social demands, and favor the sedimentation of nursing as an important and indispensable profession in the health sector ${ }^{(18)}$.

The scheduling of the $7^{\text {th }}$ SINADEn provided the deepening of concepts, methods and strategies for the Systematization of Nursing Care; the exchange of knowledge on the construction and use, at national and international levels, of classification systems useful for nursing practice; the sharing of proposals for the continuity of the ICNPCH INC-ABEn Project developed in Brazil; and the favoring of articulations and partnerships for the development of professional practice in the country ${ }^{(18)}$.
In 2006, ABEn Nacional celebrated its $80^{\text {th }}$ anniversary, the ABEn - Paraíba Section was responsible for the execution of the $8^{\text {th }}$ SINADEn, which had as its central theme Tracing paths in the construction of a Brazilian nursing terminology. At the time, even without having a more precise notion about the differences between reference terminology and interface terminology, the Executive Committee, in defining the central theme of the event, started from the assumption that Brazilian Nursing, in its practice, uses a specialized language that reflects the diversity of its practices; establishes standards of care that can be used in any part of Brazil; and allows an improvement in the quality of nursing care record ${ }^{(19)}$.

During the event, the Board of Professional Affairs coordinated a DECIDIRE meeting, attended by members and representatives of ABEn Sections from fifteen states, with the purpose of discussing strategies to create a Brazilian nursing terminology. The result of this meeting gave form and content to João Pessoa Charter, approved in a plenary session on the occasion of the closing of the $8^{\text {th }}$ SINADEn:

Considering that the classification systems of the practice elements - diagnoses, actions or interventions and nursing outcomes - are a significant tool for communication (intra and interprofessional) and knowledge production of the area; for the visibility of the forms of organization and execution of the work of the professions; for the apprehension of the different processes that are used in practice; for the procedural evaluation of the outcomes, benefits and impacts of its actions; for professional autonomy and for strengthening the commitment of the profession to the people, families and collectivities that seek or need their care, ABEn Nacional, taking the lead in this process: it guides the Brazilian Nursing to commit to the development, deployment and use of a specialized language in the documentation and information systems of professional practice; recommends that the Board of Professional Affairs initiate the process of installing DECIDIRE in the State Sections, to socialize aspects pertinent to the theme; and is responsible for the elaboration of a broad political project, aiming at the continuity of the construction of a Brazilian nursing terminology and professional training for its use ${ }^{(20)}$.

The discussions that took place during the $8^{\text {th }}$ SINADEn pointed to the possibility that, instead of the definition by a single classification, the researchers and Brazilian scholars of the subject had the technical-scientific knowledge and the practical experience to add, to a terminology of reference, cultural and linguistic aspects of the different regions of the country, as well as the different levels of health care, in order to make it more consistent with our reality. The result could be understood as an interface terminology, with a Brazilian aspect, but there was the recognition that the fundamental aspects about Terminology were not yet mastered, whether as a process, as a product or as an area of knowledge.

The $9^{\text {th }}$ SINADEn took place in 2008, in Porto Alegre City Rio Grande do Sul State, with the central theme of the Brazilian Contribution to the development of nursing classifications. In response to the need identified in the previous event, to deepen the development of standardized language systems, Professor Maria da Graça Krieger, leader of the group responsible for the Terminológico Cone Sul Project (TERMISUL), from the Institute of 
Letras (Languages and Literature) of Universidade Federal do Rio Grande do Sul, participated in the $9^{\text {th }}$ SINADEn and spoke at the conference named Technical-scientific terminology: theoretical and methodological aspects. The program also included, among other things: the contribution of ABEn and of the Records and Information Systems for the construction of nursing terminologies; reports of experiences in the implantation and development of nursing classifications in clinical practice, teaching and nursing research; the implementation of nomenclatures within SUS and the organizational development of services ${ }^{(21)}$.

Among the referrals of $9^{\text {th }}$ SINADEn, it is worth highlighting the need to promote debates and reflections about nursing terminologies, aiming to subsidize the construction of a knowledge adhering to nursing practices; the importance of the effective participation of ABEn Nacional with public health agencies for the insertion of nursing data in the construction of the SUS unified table; the urgency to include the systematization of care and the Nursing Process during the training of nurses so that they not only know, but also apply them in their practice; and the implantation of nursing nomenclatures in SUS documentation systems and their importance for the valorization and visibility of the profession ${ }^{(21)}$.

In 2010, the $10^{\text {th }}$ SINADEn, held by ABEn - Federal District Section, was organized around the central theme Systematization of Nursing Care in Brazil: 30 years in the construction of quality care, subdivided into four thematic axes: Systematization of Nursing Care to the individual at different stages of life; Implementation of the Systematization of Nursing Care in the space of production of undergraduate and graduate education; Management and registration of nursing care; and Nursing practice information and communication systems. Two ICN representatives, Amy Coenen, Director of the ICNP ${ }^{\circ}$ Program, and Claudia Bartz, Coordinator of the e-Health Program and Manager of ICNP ${ }^{\circ}$ Centers accredited by the INC, were invited and participated in the event. The Professor Amy Coenen spoke at the opening lecture entitled The ICNP Program of the International Council of Nurses: reflections on the teaching and practice of nursing; as for Claudia Bartz spoke about the organization of the Centers for Research and Development of ICNP ${ }^{\circledR}$ accredited by the INC, describing the contribution of these Centers for the information infrastructure in Nursing. The schedule also included discussions about the use of classification systems in clinical practice: domain, autonomy and visibility of Nursing; classification systems for practice and social responsibility of Nursing; history of the Systematization of Nursing Care in Brazil; the first discussions in Brazil about classification systems and current situation in care, teaching and research; and application of the Systematization of Nursing Care in intra and extra-hospital practice ${ }^{(22)}$.

The $11^{\text {th }}$ SINADEn, held in 2013 in the city of Curitiba City Paraná State, had as its central theme Systematization of Nursing Care and social responsibility in the fields of professional practice. The event provided room for a critical reflection about the systematization of care and the Nursing Process, articulating them with social responsibility, in order to contribute: in teaching, for the construction of an autonomous professional practice; in care, for professional visibility in health services; in research, for effective changes in teaching and nursing care; and in management, for the evaluation of the impact of nursing care quality on the health of the population ${ }^{(23)}$.

The Curitiba Charter, approved at the closing session of the event, has general recommendations, including the need for commitment to the Ministries of Health and Education to include Nursing among professions whose new courses should be appreciated by the National Health Council (Conselho Nacional de Saúde). A second group of recommendations refers to the professional practice settings, pointing out the need for effective actions to: a) ensure the inclusion of the systematization of care and the Nursing Process in the transversality of training, in order to strengthen the clinical reasoning of students and prepare them to work in the different settings of professional practice; $b$ ) incorporate the systematization of care and the Nursing Process as a way to reorganize the care model and nursing practices in health systems; c) review the management model in Nursing, seeking to provide the necessary conditions for a professional care carried out with knowledge, competence, sensitivity and that is effective for the clientele; d) develop strategies for the development and application of research or other forms of knowledge production that aim at the qualification of professional practice; e) make efforts for the Ministry of Health to incorporate, among the SUS health information systems, a Nursing information system, which interacts with the others, without losing its own characteristics, and which promotes the social recognition of the profession and its visibility statistics, clinical indicators and official health reports ${ }^{(24)}$.

The next event, the $12^{\text {th }}$ SINADEn, was held in Recife City - Pernambuco State, in 2016, with the central theme Systematization of Nursing Care: advances and challenges in the quality of care, management, teaching and research. The central theme was motivated by the need to deepen the theme in the training of nursing professionals, emphasizing the systematization of care as a work tool in search of a safe, humanized scientific care in the different levels of attention to the health of the individual, family and community. The event's scheduling highlighted the steps of the Nursing Process as a cross-cutting theme, necessary to strengthen the clinical reasoning of nurses at undergraduate, lato and stricto sensu postgraduate and in the different nursing care settings $^{(25)}$.

The Recife Charter, resulting from the environment of reflection and debate produced in the sessions and other activities of the event, gained such a magnitude that makes it difficult to point out aspects of these recommendations to the detriment of others, indicating, therefore, their reading in full(26). However, because it is one of the objectives of this manuscript, the following recommendations should be highlighted: for the ABEn Nacional, to continue the effort of articulation with the Ministry of Health and similar agencies, with a view to insertion, into the health information systems of the SUS, of a system that expresses the professional action of nursing in the service to the users; for the Standing Committee on Systematization of Nursing Practice, in order to maintain a forum for continuous debate on the subject, including the development of theoretical and practical support necessary for the effective implementation and use of the Nursing Process in professional practice; for health service managers and formulators of public policies on health and health information to 
guarantee the personnel conditions, methods and instruments that enable the effective implementation of the Nursing Process in the different levels of health care of the population; for the educational institutions, so that, in the discussion of the new National Curriculum Standards, they take on the Nursing Process as the structuring axis of the nurse's training; for professionals working in health care to use standardized terminologies of nursing in clinical decision-making and care documentation, contributing to professional visibility and recognition and to the advancement of Nursing science; and for the researchers and representatives of the Nursing area in the development agencies to produce and spread knowledge focused on this theme, recognizing that the articulation between research-care-teaching-management creates the conditions for reaching the best care practices ${ }^{(26)}$.

Finally, it is necessary to make the rescue of the $13^{\text {th }}$ SINADEn which, in 2018, was held for the first time, close to another event promoted by ABEn Nacional - the $16^{\circ}$ Seminário Nacional de Diretrizes para a Educação em Enfermagem ( $16^{\text {th }}$ National Seminar of Nursing Education Standards). The ABEn - Santa Catarina Section was responsible for the execution of both events, whose central theme, National Curriculum Standards, Professional Training and Systematization of Nursing Care, was developed according to the axes Public policies of education and health and Nursing Praxis and population health. The objective of the event was to share knowledge that permeates the contemporary challenges of professional training in nursing; to socialize successful experiences about teaching-service-community integration as a strategy for professional training and the consolidation of the Systematization of Nursing Care; and to promote knowledge about the Nursing Process with regard to theoretical-methodological frameworks, clinical reasoning and standardized language systems ${ }^{(27)}$.

Approved by acclamation at the closing plenary session of the event, the Florianópolis Charter reaffirmed much of the recommendations of other SINADEn. However, among those directed to health service managers and formulators of public policies and health information: a) incorporate, in the information systems of the Brazilian Unified Health System, a nursing termbases, capable of giving statistical visibility to phenomena that require nursing intervention; b) restructure health care models, promoting the incorporation of the Nursing Process as the founding and structuring axis of nursing care; c) guarantee the personnel conditions, methods and tools that allow the effective implementation of the Nursing Process, using specific language of the profession. With regard to the Associação Brasileira de Enfermagem, represented by the Standing Committee on Systematization of Nursing Practice, the recommendations made involve, above all, the encouragement of the organization and implementation of Standing Committee on Systematization of Nursing Practice in the Sections and Nucleus of ABEn, to favor the incorporation of the Nursing Process and the use of nursing outcomes as indicators of the quality of care ${ }^{(28)}$.

\section{FINAL CONSIDERATIONS}

The manuscript was based on the assumption that Nursing is an indispensable interlocutor and a critical component in the process of production, storage and use of information in the scope of health services and actions. In this context, it is important to systematize care, which organizes professional work regarding method, personnel and tools; and the deliberate and systematic use of the Nursing Process and standardized nursing languages, with the goal of, among other possible, clinical decision-making; evaluation of the quality of care, teaching and research in the area; and the management/ administration of both human nursing resources and the physical and material aspects involved in the care process.

The Simpósio Nacional de Diagnóstico de Enfermagem has represented a space for discussion and reflection on the systematization of care and the Nursing Process and on the elements of professional practice - diagnoses, outcomes and nursing interventions - whose identification and inclusion in standardized language systems are fundamental for the development of Nursing as a discipline and profession.

The historical retrieval made it possible to identify advances and permanencies, both in the themes that guided the organization and execution, as well as in the recommendations resulting from the different editions of the event. Above all, it demonstrated that the movement of creation and exchange of knowledge about the systematization of care, Nursing Process and standardized nursing language systems have undoubtedly contributed to the construction of a fertile field of knowledge for Nursing.

\section{REFERENCES}

1. Garcia TR, Nóbrega MML. Teorias de enfermagem. In: Garcia TR, Egry EY, editors. Integralidade da atenção no SUS e sistematização da assistência de enfermagem. Porto Alegre: Artmed; 2010. p.31-40.

2. Conselho Internacional de Enfermeiros. CIPE Versão 1: Classificação Internacional para a Prática de Enfermagem. São Paulo: Algol; 2007.

3. Garcia TR, Cubas MR, editors. Diagnósticos, Intervenções e Resultados de Enfermagem: subsídios para a sistematização da prática profissional. Rio de Janeiro: Elsevier; 2012.

4. De Carvalho EC, Cruz DALM, Herdman TH. Contribuição das linguagens padronizadas para a produção do conhecimento, raciocínio clínico e prática clínica da Enfermagem. Rev Bras Enferm [Internet]. 2013 [cited 2018 Nov 09];66(esp):134-41. Available from: http://www.scielo.br/ pdf/reben/v66nspe/v66nspea17.pdf

5. Grupo de Interesse em Diagnósticos de Enfermagem - GIDE SP. Anais. I Simpósio Nacional sobre Diagnósticos de Enfermagem - SNDE. 1991 Nov 19-21; São Paulo (SP). São Paulo (SP): GIDE SP; 1991.

6. Cianciarullo TI. O contexto do diagnóstico de enfermagem. In: Grupo de Interesse em Diagnósticos de Enfermagem - GIDE SP. Anais. I Simpósio Nacional sobre Diagnósticos de Enfermagem - SNDE. 1991 Nov 19-21; São Paulo (SP). São Paulo: GIDE SP; 1991. p.1-5. 
7. Perez VLAB, Nóbrega MML, organizadoras. Anais. II Simpósio Nacional sobre Diagnóstico de Enfermagem - SNDE, III Seminário Paraibano de Diagnóstico de Enfermagem - SPDE. 1992 Jul 28-31; João Pessoa (PB). João Pessoa (PB): Persona; 1992.

8. Nóbrega MML, Garcia TR, editors. Uniformização da linguagem dos diagnósticos de enfermagem da NANDA: sistematização das propostas do II SNDE. João Pessoa: CNRDE/GIDE; 1994.

9. Egry EY, Antunes MJM, Lopes MGD. Projeto CIPESC CIE-SBEn. In: Garcia TR, Egry EY, editors. Integralidade da atenção no SUS e sistematização da assistência de enfermagem. Porto Alegre: Artmed; 2010. p.175-91.

10. Clark J. An International Classification for Nursing Practice: limits and perspectives. In: Anais. I Simpósio Internacional sobre Diagnóstico de Enfermagem - SIDE; 1995 Oct 20-22; São Paulo (SP). São Paulo: Escola de Enfermagem da USP, Departamento de Enfermagem MédicoCirúrgica; 1995. p.34-45.

11. Associação Brasileira de Enfermagem / Associação Brasileira de Enfermagem Seção Ceará. SINADEN III / ECDE I. Programa do III Simpósio Nacional sobre Diagnóstico de Enfermagem e I Encontro Cearense sobre Diagnóstico de Enfermagem; 1996 Nov 25-27; Fortaleza, CE. Fortaleza: ABEn; 1996

12. Guedes MVC, Araújo TL, organizadoras. O uso do diagnóstico na prática de enfermagem. 2.ed. Brasília: Associação Brasileira de Enfermagem; 1997. (Série Didática: Enfermagem no SUS).

13. Anais. IV Simpósio Nacional sobre Diagnóstico de Enfermagem - SINADEn; 1998 May 10-13; Curitiba (PR). Curitiba (PR): ABEn; 1998.

14. Programa e Resumos. I Simpósio Internacional de Classificação da Prática de Enfermagem em Saúde Coletiva - SICPESC, V Simpósio Nacional de Diagnóstico de Enfermagem Associação Brasileira de Enfermagem - SINADEn. 2000 May 23-26; João Pessoa (PB). João Pessoa: ABEn; 2000.

15. Garcia TR, Nóbrega MML, editors. Sistemas de classificação da prática de enfermagem: um trabalho coletivo. João Pessoa: Associação Brasileira de Enfermagem, Ideia; 2000. (Série Didática: Enfermagem no SUS).

16. Livro Programa. VI Simpósio Nacional de Diagnóstico de Enfermagem - SINADEn, I Simpósio Internacional sobre Classificações de Enfermagem - SINCE. 2002 Aug 7-9; São Paulo (SP). São Paulo: ABEn; 2002.

17. Relatório Científico. VI Simpósio Nacional de Diagnóstico de Enfermagem - SINADEn, I Simpósio Internacional sobre Classificações de Enfermagem - SINCE. 2002 Aug 7-9; São Paulo (SP). São Paulo: ABEn; 2002.

18. Chianca TCM, Rocha AM, Pimentel MO, organizadoras. Anais. VII Simpósio Nacional de Diagnóstico de Enfermagem - SINADEN; 2004 Jun 29-May 1; Belo Horizonte (MG). Belo Horizonte (MG): ABEn; 2004.

19. Oliveira EF, Nóbrega MML, Soares MJGO, editors. Anais. VIII Simpósio Nacional de Diagnóstico de Enfermagem - SINADEN; 2006 23-26 May; João Pessoa (PB). João Pessoa (PB): UFPB; 2006.

20. Carta de João Pessoa. VIII Simpósio Nacional de Diagnóstico de Enfermagem - SINADEN. 2006 23-26 May; João Pessoa (PB). João Pessoa (PB): ABEn; 2006.

21. Associação Brasileira de Enfermagem / Associação Brasileira de Enfermagem Seção Rio Grande do Sul. SINADEn IX. Relatório Científico do IX Simpósio Nacional de Diagnóstico de Enfermagem; 2008 May 26-29; Porto Alegre, RS. Porto Alegre: ABEn; 2008.

22. Anais. Sistematização da assistência de enfermagem no Brasil: 30 anos na construção da qualidade no cuidar. 10th SINADEn: Simpósio Nacional de Diagnóstico em Enfermagem [Internet].; 2010 Aug 04-07; Brasília (DF). Brasília (DF): ABEn; 2010. [cited 2018 Nov 09] Available from: http://www.abeneventos.com.br/10sinaden/anais/files/completo.pdf

23. Anais. Sistematização da assistência de enfermagem e responsabilidade social nos cenários da prática profissional. 11th SINADEn: Simpósio Nacional de Diagnóstico em Enfermagem [Internet]. 2013 Aug 01-03; Curitiba (PR). Curitiba (PR): ABEn; 2013. [cited 2018 Nov 09] Available from: http://www.abeneventos.com.br/anais_sinaden/11sinaden/index.html

24. Carta de Curitiba para a enfermagem brasileira. 11th SINADEn: Simpósio Nacional de Diagnóstico em Enfermagem [Internet]. 2013 Aug 01-03; Curitiba (PR). Curitiba: ABEn; 2013. [cited 2018 Nov 09] Available from: http://www.abeneventos.com.br/11sinaden/arquivo/CARTADE-CURITIBA.pdf

25. Anais. 12th SINADEn: Simpósio Nacional de Diagnóstico em Enfermagem. 2016 Jun 15-18; Recife (PE). Recife (PE): ABEn; 2016. [cited 2018 Nov 09]. Available from: http://www.abeneventos.com.br/12sinaden/anais

26. Carta de Recife. 12th SINADEn: Simpósio Nacional de Diagnóstico em Enfermagem [Internet]. 2016 Jun 15-18; Recife (PE). Recife (PE): ABEn; 2016. [cited 2018 Nov 09] Available from: http://www.abennacional.org.br/documentos/CartaRecife_12_SINADEn.pdf

27. Apresentação. 16th SENADEn: Seminário Nacional de Diretrizes, 13th SINADEn: Simpósio Nacional de Diagnóstico de Enfermagem [Internet]. 2008 Jun 05-08; Florianópolis (SC). Florianópolis: ABEn; 2018 [cited 2018 Nov 09]. (Anais do XIII Simpósio Nacional de Diagnóstico de Enfermagem). Available from: http://www.abeneventos.com.br/16senaden/anais/edicao-apresentacao.htm

28. Carta de Florianópolis. 16th SENADEn: Seminário Nacional de Diretrizes, 13th SINADEn: Simpósio Nacional de Diagnóstico de Enfermagem [Internet]. 2008 Jun 05-08; Florianópolis (SC). Florianópolis: ABEn; 2018 [cited 2018 Nov 09]. (Anais do XIII Simpósio Nacional de Diagnóstico de Enfermagem). Available from: http://www.abeneventos.com.br/16senaden/anais/edicao-carta.htm 